\title{
The prevalence and patterns of endocrinopathies amongs azoospermic male partners at a fertility clinic in Benin City
}

\begin{abstract}
Aim and Objective: We undertook this study to evaluate the prevalence, trend and patterns of endocrine abnormalities among azoospermic male partners of infertile couples investigated for male infertility in our fertility centre.
\end{abstract}

Setting: A private IVF hospital treating infertility with assisted reproduction technology in Benin City, Nigeria.

Methodology: A prospective, observational and a descriptive study of the analysis of the hormonal profile of azoospermic male partners of the infertile couples, who presented at St Augustine Medical center, Benin City, Nigeria over a five-year period from May 2007 through December 2012 was undertaken.

Results: A total of 686 men were investigated for infertility within this period, fifty-eight $(8.45 \%)$ of them with a mean age of $43.72 \pm 1.5$ years were found to be azoospermic. Of the 58 azoospermic men, fourty-eight $(82.76 \%)$ had one or more abnormal hormonal profile parameter, while ten $(17.24 \%)$ had a normal hormone profile pattern. Of the forty-eight Azoospermic men with abnormal hormone profile pattern, twenty-two (37.93\%) had increased serum FSH and LH, mildly increased prolactin and low testosterone, $15(25.86 \%)$ had increased serum FSH, normal LH and prolactin with reduced testosterone, $4(6.9 \%)$ had increased serum LH, normal FSH and prolactin with reduced testosterone, $2(3.45 \%)$ had low LH, FSH and testosterone with high prolactin while 5 (10.42\%) had elevated prolactin levels, normal gonadotrophins (LH \& FSH) and low testosterone. Ejaculate volume was normal in $48(82.76 \%)$ of the azoospermic men when the mean semen volume was $3.30 \pm 0.19 \mathrm{mls}$; and mean serum hormone levels were LH; $9.54 \pm 0.89, \mathrm{FSH} ; 22.77 \pm 2.70$, Prolactin; $18.54 \pm 2.50$, Testosterone; $3.01 \pm 0.22$. The ejaculate volume was low in 10 $(17.24 \%)$ men with a mean semen volume of $0.89 \pm 0.07$ and mean serum hormone levels; LH; $13.75 \pm 3.12$, FSH; $23.48 \pm 4.45$, Prolactin; $15.87 \pm 2.46$, Testosterone; $3.08 \pm 0.46$.

Conclusion: Endocrinopathies are common among azoospermic male partners of infertile couples in Benin City. The most prevalent pattern of endocrinopathy suggests testicular failure. Majority of men don't show-up early enough for infertility screening. Azoospermia was most prevalent among business men followed by civil servants. The main reason for the endocrinopathies is not clear, but exposures to certain environmental/occupational factors which can disrupt endocrine function are likely to be contributory.

Keywords: prevalence, endocrinopathies, azoospermia, Benin City
Volume I Issue I - 2014

\author{
Uhuonrenren Osaretin Benjamin, ${ }^{1,2}$ \\ Theophilus lyayi Akhere, ' AAE Orhue ${ }^{1,3}$ \\ 'Andrology Unit, St. Augustine Medical Center and Assisted \\ Reproduction Technology Unit, Nigeria \\ ${ }^{2}$ Departments of Human Physiology, University of Benin, Nigeria \\ ${ }^{3}$ Obstetrics and Gynecology Department, The University of \\ Benin Teaching Hospital, Nigeria \\ ${ }^{4}$ Department of Medical Laboratory Sciences, Ambruse Alli \\ University, Nigeria
}

Correspondence: Uhuonrenren Osaretin Benjamin, Andrology Unit, St. Augustine Medical Center and Assisted Reproduction Technology Unit, Nigeria, Tel +2348057427876, Email uhuonrenrenosaretin@gmail.com

Received: October 21, 2014 | Published: December 22, 2014
Abbrevations: FSH, follicle stimulating hormones; LH, luteinizing hormone; ICSI, intracytoplasmic sperm injection; IVF, in vitro fertilization; WHO, world health organization; ISO, international standard organization; SEM, standard error of the mean; LHRH, luteinizing hormone-releasing hormone; TESE, testicular sperm extraction

\section{Introduction}

In contemporary medical practice, infertility is defined as the inability to achieve pregnancy within one-year duration of regular (evenly spaced 48hours interval) ejaculatory vaginal sexual intercourse without contraception between a man and a woman in the reproductive age. ${ }^{1}$ It occurs worldwide but differs in incidence and prevalence. It is a sensitive issue in our environment and a social stigma in many Nigerian cultures. Historically, infertility is considered a woman's disease. It is only within the last fifty years that the importance of the male factor contribution to infertility has been recognized. ${ }^{2}$ Previous research has shown that Male factor infertility represents about $35 \%$ of all infertility cases when diagnosis is based on the presence of abnormal parameters on a semen analysis. ${ }^{3}$ In Nigeria, male infertility due to poor semen quality contributes to 20 $48 \%$ of all infertile couples. ${ }^{4-6}$ Hence, the investigation and treatment of male factor of infertility is equally as important as the treatment of the female factor. Azoospermia, as a male factor is present in about $1 \%$ of all men ${ }^{7}$ and in approximately $15 \%$ of infertile men. ${ }^{8}$ The further evaluation of a patient with azoospermia is important to establish 
the underlying cause ${ }^{9-11}$ Endocrine disorders has been suggested as a disorder associated with azoospermia in some previous studies, yet assessment of the hormone profile is not a frequent part of the work up of the male partner in infertile couples. This study was therefore designed to assess the pattern and prevalence of endocrine disorder in the azoospermic male in infertility work up.

\section{Materials and methods}

\section{Study design}

A prospective and descriptive study was conducted on men investigated for infertility at St Augustine Medical Centre and Assisted Conception Unit, Benin City, Nigeria over a five-year period from May 2007 to December $31^{\text {st }} 2012$.

\section{Specimen collection}

A total of 686 men were referred to the Andrology laboratory unit for semen analysis and semen samples were collected in sterile universal plastic containers mostly by masturbation, but in some cases by coitus interruption after 3-5 day abstinence from sexual intercourse and were delivered to the laboratory within 1 hour of collection.

\section{Specimen and sample analysis}

We employed the Kruger Strict Criteria approved by the World Health Organization (WHO) to evaluate the following characteristics; semen $\mathrm{pH}$, Semen volume (ml), Sperm count (millions/ml), Motility $(\%)$, Viability $(\%)$, Sperm morphology or shape (\%) and additional semen contents, such as white blood cells, which are an indication of infection. The sperm concentrations were determined by using Markler counting Chamber (Semen Analysis Chamber, ISO 9001:2000, by Sefi Medical Instruments, Heifa, Israel). The Olympus ${ }^{\circledR}$ Binocular microscope with magnification (x10) was used to observe the sperm cells. Those that were found to be azoospermic were further confirmed by examination of the pellet of centrifuged semen sample and a repeat on at least two occasions at eight weeks interval. ${ }^{12}$ Blood samples for hormone assay were collected in a plain, sterile container after an overnight abstinence from meat/protein intake and a 1-hour rest. Samples were left for some time to clot and serum extracted by centrifugation at $1000 \mathrm{~g}$ for $10 \mathrm{mins}$. Serum was stored frozen at $-20^{\circ} \mathrm{C}$ until analysis. Serum follicle stimulating hormone (FSH), luteinizing hormone (LH), testosterone and prolactin were assayed using the enzyme-linked immune sorbent assay method. Twenty normospermic males matched for age, occupation and education were included as control subjects. Their blood samples were also obtained for estimation of follicle stimulating hormone (FSH), luteinizing hormone ( $\mathrm{LH})$, testosterone and prolactin in the same order as the study. Information regarding the past medical history, social history, physical examination of the testes and results of semen analysis were extracted from medical records of individual patients.

\section{Statistical analysis}

Differences in the respective mean values of hormones and semen volume between normospermic male control subjects and each pattern of endocrinopathies identified were assessed using Students t-test. Level of significance was set as 0.01 . Results were presented as mean and standard error of the mean (SEM).

\section{Results}

Of the 686 men who were investigated for infertility, fifty-eight $(8.45 \%)$ of them with a mean age of $43.7 \pm 1.5 y$ years were found to be azoospermic.
Of the 58 azoospermic men, forty-eight $(82.76 \%)$ had one or more abnormal hormone profile parameter, while ten (17.24\%) had a normal hormone profile pattern.

Of the forty-eight Azoospermic men with abnormal hormone profile pattern, twenty-two $(37.93 \%)$ with a mean age of $41.68 \pm 2.07$ years had statistically significant $(\mathrm{P}<0.01)$ increased serum FSH \& LH, mildly/moderately increased prolactin, and low testosterone $(\mathrm{P}<0.01)$ as shown in Table 1(A).

$2(3.45 \%)$ with a mean age of $41.5 \pm 2.5$ years had low $\mathrm{LH}, \mathrm{FSH}$ and testosterone $(\mathrm{P}<0.01)$ but high prolactin $(\mathrm{P}<0.01)$ as shown in Table 1(B).

$4(6.9 \%)$ with a mean age of $45 \pm 4.39$ years had increased serum LH $(\mathrm{P}<0.01)$, normal FSH and prolactin $(\mathrm{P}>0.01)$ with reduced testosterone concentration $(\mathrm{P}<0.01)$ as shown in Table $1(\mathrm{C})$.

$5(10.42 \%)$ with a mean age of $39.5 \pm 2.09$ years had elevated prolactin $(\mathrm{P}<0.01)$ levels with normal levels of FSH and LH $(\mathrm{P}>0.01)$ but low testosterone $(\mathrm{P}<0.01)$ as shown in Table 1(D).

$15(25.86 \%)$ with a mean age of $43.6 \pm 1.35$ years had increased FSH $(\mathrm{P}<0.01)$, normal LH and prolactin $(\mathrm{P}>0.01)$ with reduced testosterone $(\mathrm{P}<0.01)$ as shown in Table $1(\mathrm{~F})$.

$10(17.24 \%)$ of the 58 azoospermic men with a mean age of $44.7 \pm 3.26$ years had normal serum hormone profile pattern as shown in Table 1(E).

Of the 58 azoospermic men investigated, 16 ( 27.59\%) were Civil servant $(12.07 \%$ and $15.52 \%$ were teachers and non teaching civil servants respectively). 18 (31.03\%) of them were business men, 6 $(10.34 \%)$ of them live abroad, $3(5.17 \%)$ were drivers, $1(1.72 \%)$ was farmer, $6(10.34 \%)$ were artisans (carpenters, Bricklayers and Mechanic), 2 (3.45\%) were clergy-men, 2 (3.45\%) were retired, 2 $(3.45 \%)$ were lawyers, $1(1.72 \%)$ was accountant and $1(1.72 \%)$ was engineer.

According to their ejaculate volume (Table 2A), 48 (82.76\%) of the azoospermic men with a mean age of $41.5 \pm 2.5$ years had normal semen volume with mean semen volume $(\mathrm{ml})$ of $3.30 \pm 0.19 \mathrm{ml}$, their mean serum hormones were; LH; 9.54 \pm 0.89 , FSH; 22.77 \pm 2.70 , Prolactin; $18.54 \pm 2.50$, Testosterone; $3.01 \pm 0.22$, while $10(17.24 \%)$ with mean age of $42.3 \pm 1.5$ years had a mean semen volume of $0.89 \pm 0.07 \mathrm{ml}$, with mean serum hormones as follow; LH; $13.75 \pm 3.12$, FSH; $23.48 \pm 4.45$, Prolactin; $15.87 \pm 2.46$, Testosterone; $3.08 \pm 0.46$. Of the 58 azoospermic men, 2 (3.45\%) had significant pus cells (5-6cells/ hpf) and culture yielded growth of staphylococcus aureus in the two. Others had no significant growth after 24 hours incubation at $37^{\circ} \mathrm{C}$, hence infection had a low prevalence.

\section{Discussion}

Azoospermia is one of the common causes of male infertility in Nigeria and sub Saharan Africa. From this study, we found that hormonal abnormality underlying testicular dysfunction were common among this group of infertile azoospermic men. Fifty-eight (8.45\%) (Mean age: $43.72 \pm 1.5$ years) of the men investigated for male infertility within the period of study were found to be azoospermic. This was closely related to the studies conducted in Jos Nigeria where $9.9 \%$ of men evaluated for male infertility were found to be azoospermic. ${ }^{13}$ Studies in Owo, Nigeria in 2012 revealed that $13.9 \%$ of men investigated for infertility were azoospermic. ${ }^{14}$ Studies in Illorin, Nigeria in 2012 found a much higher prevalence (35.6\%) of azoospermia among men investigated for infertility. ${ }^{15}$ Studies 
have shown that the two major causes of azoospermia are failure of spermatogenesis and bilateral ductal obstruction. ${ }^{16,17}$ Results from this study also suggest that these men showed up late to the hospital for investigation (The mean age of the 58 azoospermic men was $43.72 \pm 1.5$ years). It has been shown that semen qualities deteriorate by as much as $3 \%$ per year. ${ }^{18-20}$ The prevalence of endocrinopathy in azoospermic men in the present study of $82.76 \%$ was higher than that reported in Kano, Nigeria in 2006 which was $60 \%{ }^{21}$ and that reported in Illorin, Nigeria 2012 which was $46.7 \% .{ }^{15}$ Perhaps, more men are becoming more enlightened on the importance of male factor screening and contribution to infertility treatment.

Table I Mean serum Hormone profile results of Normospermic male controls and the 58 different patterns of endocrinopathies among Azoospermic men (mean \pm SEM)

\begin{tabular}{|c|c|c|c|c|c|c|}
\hline Azoospermic groups & $\begin{array}{l}\text { Mean age } \\
\text { (yrs) }\end{array}$ & $\begin{array}{l}\text { Prolactin } \\
\text { (ng/ml) }\end{array}$ & $\begin{array}{l}\text { FSH (miul } \\
\mathrm{ml})\end{array}$ & LH (miu/ml) & $\begin{array}{l}\text { Testosterone } \\
\text { (ng/ml) }\end{array}$ & $\begin{array}{l}\text { Prevalence } \\
\text { (n) }\end{array}$ \\
\hline $\begin{array}{l}\text { (B) Hyponadotropic } \\
\text { hypogonadism \& high } \\
\text { prolactin }\end{array}$ & $41.5 \pm 2.5$ & $43.85 \pm 3.19$ & $0.95 \pm 0.55$ & $0.80 \pm 0.70$ & $2.30 \pm 0.80$ & $2(3.45 \%)$ \\
\hline $\begin{array}{l}\text { (C) Isolated increase in LH \& } \\
\text { low testosterone }\end{array}$ & $45 \pm 4.39$ & $12.48 \pm 1.84$ & $5.43 \pm 1.13$ & $13.98 \pm 1.93$ & $2.40 \pm 0.55$ & $4(6.90 \%)$ \\
\hline $\begin{array}{l}\text { (D) Normal gonadotrophins, } \\
\text { low testosterone \& high } \\
\text { prolactin }\end{array}$ & $39.5 \pm 2.09$ & $32.4 \pm 0.94$ & $4.46 \pm 0.23$ & $3.96 \pm 0.19$ & $1.87 \pm 0.35$ & $5(8.62 \%)$ \\
\hline $\begin{array}{l}\text { (E) Normal serum hormone } \\
\text { profile }\end{array}$ & $44.7 \pm 3.26$ & $10.03 \pm 0.84$ & $6.18 \pm 0.72$ & $4.19 \pm 0.36$ & $4.29 \pm 0.27$ & 10 (I7.24\%) \\
\hline $\begin{array}{l}\text { (F) Isolated increase in serum } \\
\text { FSH \& low testosterone }\end{array}$ & $43.6 \pm 1.35$ & $|4.87 \pm 3.0|$ & $26.33 \pm 2.80$ & $6.24 \pm 0.55$ & $2.21 \pm 0.27$ & I5 (25.86\%) \\
\hline $\begin{array}{l}\text { Normospermic male } \\
\text { controls. (68.4 million } \pm 3.4)\end{array}$ & $40.42 \pm 0.34$ & I I. $.55 \pm 0.40$ & $5.96 \pm 0.20$ & $3.98 \pm 0.14$ & $4.7 \pm 0.13$ & 20 \\
\hline
\end{tabular}

Among the forty-eight azoospermic men with hormonal profile abnormality in one or more parameters (endocrinopathies), the pattern/type of abnormality however varied, twenty-two $(37.93 \%)$ had statistically significant increased serum FSH and LH, mildly/ moderately increased prolactin $(\mathrm{P}<0.01)$ but low testosterone $(\mathrm{P}<0.01)$ when compared with respective serum hormones of normospermic control group as shown in Table 1(A). This pattern is consistent with hypergonadotropic hypogonadism. Although the prolactin increase was statistically significant when compared with that in the control group, it was not clinically significant considering the clinical reference range of prolactin in men $(2.5-17.0 \mathrm{ng} / \mathrm{ml})$ hence we considered it as "mildly/moderately increased". The pathophysiology and mechanism(s) behind increased prolactin, LH \& FSH with low testosterone in azoospermic men in our locality is not clear yet, but studies $^{22}$ have reported "Hyperprolactinemia and hypergonadotropins in infertile males with severe oligospermia and azoospermia" at Jordan in 2006. Our finding is also similar to the research works done in Illorin, Nigeria in 2012, ${ }^{15}$ their findings were as follows; "the hormone profile for patients having azoospermia showed LH; 21.84 \pm 12.5 ; FSH; 14.14 \pm 4.4; Testosterone; 6.63 \pm 2.09 ; and Prolactin; $15.03 \pm 2.91$. The prevalence from this study was also very similar to that found by studies in Maiduguri, Nigeria in 2008 where 40 (41.7\%) patients had hypergonadotrophic hypogonadism. ${ }^{23}$ Studies have also found strong positive correlations between FSH and LH levels, which were also negatively correlated with serum testosterone level. ${ }^{24}$ This pattern of endocrinopathy is an indication of testicular failure in which there is loss of negative feedback by testicular products. Hypogonadism is a medical term which describes a diminished functional activity of the gonads that may result in diminished sex hormone biosynthesis and impaired gamete or no gamete production and regulation. Serum LH \& FSH are usually elevated because of the lack of negative feedback from the requisite rise in testosterone production indicating testicular failure. At certain yet to be determined plasma threshold of FSH and $\mathrm{LH}$, the high gonadotrophin level exercise a negative feedback effect on the hypothalamic-pituitary-testicular axis and thus the plasma testosterone become low or normal. ${ }^{25}$

$15 / 58(25.86 \%)$ had increased serum FSH, normal prolactin and reduced testosterone as shown in Table 1(F). Studies by Masanori et al in 1995 revealed that azoospermic men with high FSH \& normal LH had significantly lower inhibin and testosterone levels when compared with normal men. ${ }^{24}$ Therefore, dual control of FSH by inhibin and testosterone may be plausible and might explain our present results, which also corroborates Tsatsoulis's paradoxical findings. Other investigators provided the evidence in support of the hypothesis that serum FSH secretion is regulated by the negative feedback from two testicular endocrine factors: testosterone and inhibin. ${ }^{26}$ 
4/58 (6.9\%) had increased serum LH, normal prolactin \& FSH and reduced testosterone concentration. LH stimulates the production of testosterone by the Leydig cells, which in turn acts on the sertoli and peritubular cells of the seminiferous tubules to stimulate spermatogenesis [27]. Literature has shown that testosterone is essential for growth and division of germinal cells in forming spermatozoa; it also regulates its own secretion by negative feedback mechanism. It acts on hypothalamus and inhibits the secretion of luteinizing hormone-releasing hormone (LHRH). When LHRH secretion is inhibited, LH is not released from anterior pituitary, resulting in the stoppage of testosterone secretion from testes. On the other hand, when testosterone production is low, lack of inhibition of hypothalamus leads to secretion of testosterone through LHRH and $\mathrm{LH}^{28}$

$2 / 58(3.44 \%)$ of the azoospermic men had low serum gonadotrophins ( $\mathrm{LH} \& \mathrm{FSH}$ ) and hyperprolactinamia but low testosterone. This was closely related to the findings of the studies of Geidam A.D et al in 2008 where a prevalence of $4 / 58(4.2 \%)$ patients having hypogonadotrophic hypogonadism among their study group. ${ }^{23}$ Hypogonadotropic hypogonadism is a result of decreased gonadotropin stimulation of potentially normal testes. ${ }^{28,29}$ It can be caused by hypothalamic disorders, e.g., congenital abnormalities such as Kallmann syndrome or acquired pituitary disorders, e.g., functioning and non-functioning pituitary tumors. ${ }^{9}$

As shown in our result (Table 1D), hypogonadism and normogonadotropin associated with high prolactin are not a very common profile pattern but are of clinical interest. We found a prevalence of $8.62 \%$ of this pattern of endocrinopathy. Although the pathophysiological mechanism behind this pattern of endocrinopathy is not clear at the moment, we do hope that more research in future will illuminate and clarify it.

We found a prevalence of $17.24 \%$ (Table 1E) azoospermic males with normal serum hormones in this study. But studies by Masanori Y et al in 1995 found no normal hormone pattern among azoospermic. ${ }^{24}$ In 2006, studies found a prevalence of $60 \%$ of azoospermic men with normal serum hormones. ${ }^{23}$ azoospermia in association with normal serum concentration of LH, FSH and testosterone as shown in (Table $1 \mathrm{E})$ is associated with retrograde ejaculation and obstruction of the ejaculatory system. In this case, assisted reproduction technology (IVF) can be a treatment option where testicular sperm extraction (TESE) procedure is performed on the man to retrieve live sperm cells from the testis which can then be used to inseminate the wife's egg in vitro by Intracytoplasmic sperm injection (ICSI) and the resulting embryos transferred to wife's uterus for possible implantation and clinical pregnancy.

With a view to evaluating obstructive and non-obstructive causes of azoospermia among this study group, we classified the azoospermic men according to their semen volume. 10(17.24\%) of the azoospermic men had significantly low semen volume with significantly high FSH, LH and prolactin but normal testosterone. Literature has shown that azoospermic patients with low semen volume and normal sized testes may have ejaculatory dysfunction or ejaculatory duct obstruction..$^{9,10}$ This study found a prevalence of $17.24 \%$ azoospermia with low semen volume, negative seminal fructose test accompanied with hypergonadotropic hypogonadism which suggests a combined abnormality of $2^{0}$ testicular failure and ejaculatory duct obstruction. From this study also, we found that most of the azoospermic men had normal ejaculate volume. Azoospermic patients with normal ejaculate volume may have either obstruction of the reproductive system or abnormalities of spermatogenesis. In fact, FSH values in the upper normal range usually indicate impaired spermatogenesis while marked elevation of serum FSH is diagnostic of abnormal spermatogenesis, usually nonobstructive azoospermia. Although there is a well established inverse relationship between serum FSH levels and the probability of obstruction being the cause of azoospermia,,${ }^{8,9,30,31}$ patients with normal or borderline elevated serum FSH levels may have either obstruction or abnormal spermatogenesis and should therefore, undergo a diagnostic testicular biopsy.

According to their occupation, we found the highest prevalence (31.03\%) among business men, followed by civil servants $(27.59 \%)$, those living abroad $6(10.34 \%)$, artisans $6(10.34 \%)$, clergy men, lawyers and retired $2(3.45 \%)$ each. The least prevalence was found among farmers, engineers, and accountants (1.72\% each). This was different from the outcome of the studies in Abakilliki, Nigeria in 2008 where the highest prevalence of $86 \%$ was civil servants and $4 \%$ were farmers. ${ }^{32}$ Presently, no study has been able to prove an association between occupation and male infertility. In this study, there was no history or records of occupational exposure of our patients to environmental and chemical factors that could cause azoospermia. Although the reason for the high prevalence among business men and civil servants is not clear, it is possible that exposure to different environmental factors as they move from place to place related to their business may have contributed. Secondly, it is very clear that businessmen and civil servants are educated and enlightened about the need to seek assistance from fertility experts as well as the importance of male factor contribution to infertility and are financially empowered to cope with the cost, unlike farmers majority of whom lives in the villages, preferring traditional medicine treatment and native doctors assistance. Although accountants and engineers also had the same low prevalence as farmers, we cannot attribute it to unawareness or lack of financial empowerment since they are educated and gainfully employed.

Infection of the seminal fluid has been implicated as the major cause of azoospermia in infertile males in eastern Nigeria, since infections are known to damage the vas deferens and seminiferous tubules. ${ }^{33}$ Acute and chronic infections and consequent inflammation in the male reproductive system may compromise the sperm cell function and the whole spermatogenetic process, causing qualitative and quantitative sperm alterations. ${ }^{34}$ The bacteria responsible for semen contamination generally originate from the urinary tract of patients or can be transmitted by the partner via sexual intercourse. ${ }^{35}$ According to World Health Organization (WHO), seminal fluid infection was defined as the presence of significant bacteriospermia in the ejaculate. ${ }^{12}$ It is generally accepted that Staphylococcus aureus, which is coagulase-positive, is regarded as pathogenic and should be treated. The longer the infection persists, the greater the damage and loss of germ cells. The rate (percentage) of infection increases from normospermic to azoospermic males. ${ }^{36}$ This present study found a low prevalence of $3.46 \%$ of azoospermic men with Staph aureus infection of their seminal fluid contrary to findings of Megafu in 1991, in Eastern Nigeria. Studies have showed that $74.7 \%$ of azoospermic men had bacterial infection and $68.2 \%$ were due to Staphylococcus aureus infection. ${ }^{37}$ Other studies in 2012 found that Staphylococcus aureus as causative organism accounted for $20.3 \%$ of seminal fluid infection. ${ }^{38}$ 
Table 2 Hormone profile results of azoospermic men with normal semen ejaculate volume, low semen ejaculate volume and normospermic male control subjects

\begin{tabular}{|c|c|c|c|c|c|c|c|c|}
\hline Groups & Mean age & $\begin{array}{l}\text { Prolactin } \\
\text { (ng/ml) }\end{array}$ & $\begin{array}{l}\text { FSH } \\
\text { (miu/ml) }\end{array}$ & $\begin{array}{l}\text { LH } \\
\text { (miu/ml) }\end{array}$ & $\begin{array}{l}\text { Testosterone } \\
(\mathrm{ng} / \mathrm{ml})\end{array}$ & $\begin{array}{l}\text { Fructose } \\
\text { test }\end{array}$ & $\begin{array}{l}\text { Semen } \\
\text { volume(ml) }\end{array}$ & $\begin{array}{l}\text { Prevalence } \\
(\%)\end{array}$ \\
\hline \multicolumn{9}{|l|}{$(\mathrm{A})$} \\
\hline \multicolumn{9}{|l|}{ Azoospermia } \\
\hline $\begin{array}{l}\text { with normal } \\
\text { ejaculate volume. }\end{array}$ & $41.5 \pm 2.5$ & $18.54 \pm 2.50$ & $22.77 \pm 2.70$ & $9.54 \pm 0.89$ & $3.01 \pm 0.22$ & +ve & $3.30 \pm 0.19$ & $48(82.76 \%)$ \\
\hline (B) Azoospermia & & & & & & & & \\
\hline $\begin{array}{l}\text { with low } \\
\text { ejaculate volume. }\end{array}$ & $42.3 \pm 1.5$ & $15.87 \pm 2.46$ & $23.48 \pm 4.45$ & $13.75 \pm 3.12$ & $3.08 \pm 0.46$ & -ve & $0.89 \pm 0.07$ & $10(17.24 \%)$ \\
\hline $\begin{array}{l}\text { Normospermic } \\
\text { male controls. } \\
(68.4 \\
\text { million } \pm 3.4)\end{array}$ & $40.42 \pm 0.34$ & 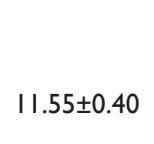 & $5.96 \pm 0.20$ & $3.98 \pm 0.14$ & $4.7 \pm 0.13$ & tve & $3.74 \pm 1.12$ & 20 \\
\hline
\end{tabular}

\section{Conclusion}

Endocrinopathies are common among azoospermic male partners of infertile couples in Benin City. The pattern and type of endocrinopathy however varied. Most of them had low testosterone in addition to other abnormal endocrine pattern. The most common type of endocrinopathies being hypergonadotrophic hypogonadism with mild hyperprolactinemia $(37.93 \%)$, followed by increase in FSH with reduced testosterone $(25.86 \%)$, and then increased prolactin, low testosterone with normal gonadotrophins (10.42\%), then increased LH with low testosterone (6.9\%) and the least prevalence is hypogonadotrophic hypogonadism with hyperprolactinamia $(3.45 \%)$. This study corroborates previous findings that failure of spermatogenesis is a leading cause of azoospermia in Benin City. More than two-third of the azoospermic men had normal ejaculate volume, normal color and normal viscosity; this shows their very low predictive value for detecting azoospermia or abnormality of sperm quality. There is urgent need for men to accept responsibility for their contribution to infertility and to willingly and voluntarily approach fertility experts as early as possible. It has been shown that semen qualities deteriorate by as much as $3 \%$ per year. ${ }^{3}$ The prevalence of bacterial infection due to Staphylococcus aureus among azoospermic men receiving treatment in Benin City is low (3.46\%), which suggests it is not a major cause of azoospermia in Benin City. We advice men to reduce stigmatization and ostracizing of women for infertility reasons as women alone are not responsible for infertility. The main reason for endocrinopathies are not known, but possible exposure to certain environmental factors which could result in endocrine function perturbations are likely to be contributory.

\section{Acknowledgments}

None.

\section{Conflict of interest}

The author declares there is no conflict of interest.

\section{References}

1. Orhue AAE. From barrenness to abundance of the fruits of the womb: The role of medical science in the fulfillment of the divine injunction (2013). Inaugural lecture series 131, University of Benin press, University of Benin, Benin city, Nigeria, p. 5.

2. Isselbacher K, Braunwald E, Wilson J. Harrison's Principles of Internal Medicine. 13th edn. New York, McGraw Hill. 1994, pp. 2006-2017.
3. Carlsen E, Giwercman AJ, Keiding N, et al. Decline in semen quality from 1930 to 1991. Ugeskr Laeger. 1993;155(33): 2530-2535.

4. Abdulhadi SK, Kawo AH, Hamza S. Semen Parameters of infertile Out Patients attending Murtala Muhammed Specialist Hospital, Kano, Nigeria. International J Biomed Health Sci. 2007;3:7-10.

5. Adeniji RA, Olayemi O, Okunlola MA, et al. Pattern of semen analysis of male partners of infertile couples at the University College Hospital, Ibadan. West Afr J Med. 2003;22(3):243-245.

6. Ajabor LM, Ezimokhai M, Kadiri A. Male contribution to sub-fertility in Benin City, Nigeria. Trop J Obstet Gynaecol. 1981;2:53-56.

7. Agu O, Ibrahim SA, Muhammed Z, (2014) Determination of the semen quality in male partners of infertile couples in Aminu Kano Teaching Hospital, Kano. Ibom medical journal 4(1): 23.

8. Jarow JP, Espeland MA, Lipshultz LI. Evaluation of the azoospermic a Patient. J Urol. 1989;142(1): 62-65.

9. Jonathan J, Mark S, Peter N. The Evaluation of the Azoospermic male; AUA statement (2010). American Urological Association Education and Research, Inc. p. 23.

10. Willott GM. Frequency of azoospermia. Forensic Sci Int. 1982;20(1):910 .

11. Nagvenkar P, Desai K, Hinduja I, et al. Chromosomal studies in infertile men with oligozoospermia and non Obstructive azoospermia. Indian $J$ Med Res. 2005;122(1):34-42.

12. World Health Organisation (WHO). Laboratory manual for examination of human semen and semen- cervical mucus interaction. $\left(3^{\text {rd }}\right.$ edn $)$, Cambridge University Press, 1999; pp. 1-65.

13. Imade GE, Sagar AS, PamI OA. Semen quality in male partners of infertile couples in Jos. Nigeria. Tro J Obstet Gynecol. 2004;17(1):24 33.

14. Fadahunsi AA, Osuolale O, Okon E. Semen Analysis of infertile Male in Owo, Nigeria. Fertility and Reprod Med. 2004;1271:57-59.

15. Jimoh AAG, Olawuyi TS, Omotoso GO, et al. Semen Parameters and Hormone Profile of Men Investigated for Infertility at Midland Fertility Centre, Ilorin, Nigeria. Journal of Basic \& applied Sciences. 2012;8:110-113.

16. Oghagbon EK, Jimoh AAG, Adebisi SA. Seminal Fluid Analysis and Biophysical Profiles: Findings and relevance in infertile males in Ilorin, $\quad$ Nigeria. Afr J Clin Exp Microbiol. 2004;5:280-284.

17. Ojengbede AO, Omonria WE, Ladipo AO. Screening for obstruction of the vas deferens in Nigerian men with azoospermia using the $\mathrm{x}$ glucosidase reaction in semen. Afri J Med Sci, 1992;21:79-81. 
18. Auger J, Kunstmann JM, Czyglik F, et al. Decline in semen quality among fertile men in Paris during the last 20years. $N$ Engl $\mathrm{J}$ Med. 1995;332(5): 281-285.

19. Carlsen E, Giwercman A, Keiding N, et al. Evidence for decreasing quality of semen during past 50 years. BMJ. 1992;305(6854):609-613.

20. Carlsen E, Giwercman A, Keiding N, et al. Declining semen quality and increasing incidence of testicular cancer: is there a common cause? Environ Health Perspect. 1995;103(Suppl 7):137-139.

21. Emokpae MA, Uadia PO, Mohammed AZ, et al. Hormonal abnormalities in azoospermic men in Kano, North Nigeria. Indian J med Res. 2006;124(3):299-304.

22. H Al-Daghistani, M Abdel-Dayem. Hyperprolactinemia and hypergonadotropins in infertile males with severe Oligospermia and Azoospermia. The internet journal of Endocrinology. 2006;3(1)

23. Geidam AD, Yawe KD, Adebayo AE, et al. Hormonal profile of men investigated for infertility at the University of Maiduguri in Northern Nigeria. Singapore Med J. 2008;49(7):538-541.

24. Masanori Y, Satoshin K, Keisure Y, et al. Serum inhibin levels in normal men and men with idiopathic infertility. Nagoya $J$ med. 1995;58(12);35-39.

25. Olooto WE, Amballi AA, Adeleye AO. Evaluation of hormonal and physical factors responsible for male Infertility in Sagamu South Western Nigeria. Der Pharmacia Lettre. 2012;4(5):1475-1479.

26. De Jong FH, Robertson DM. Inhibin 1985: Update on action and purification. Mol Cell Endocrinol. 1995;42(2):95-103.

27. Donnel LRI O, Mc Lachlan NG, Wreford and Robertson DM. Endocrinology. 1994;135(4):2608-2614.

28. Sembulingam K, Sembulingam P. Essentials of Medical Physiology, 4th edition, 2006, pp. 423-427.
29. Martin FM. Hormones of reproductive system in Fundamental of anatomy and physiology (2001), 5th ed., New Jersey, Prentice Hall, 1057.

30. Schoor RA, Elhanbly S, Niederberger CS, et al. The role of testicular biopsy in the modern management of male infertility. $J$ Urol. 2002;167(1):197-200

31. Subhan F, Tahir F, Ahmed R. The study of azoospermic patients in relation to their hormonal profile (LH, FSH and testosterone). Rawal Med J. 1995;22:25-27.

32. Ugwu EI, Ugwu NC, Ejimekeme BN. Prevalence of low sperm count and abnormal semen parameters in male partners of women consulting at infertility clinic in Abakiliki, Nigeria. Afr J Reprod Health. 2008;12(1):67-73.

33. Megafu U. Seminal fluid infection and oligospermia. Trop J Obstet Gyneacol. 1991;9:10-12.

34. Palleti D, Mylonakis I, Bertoloni G, et al. Genital tract infection and infertility. Eur j Obstet Gynecol Repro Biol. 2008;140(1): 3-11.

35. Purvis K, Christiansen E. Infection in the male reproductive tract Impact, diagnosis and treatment in relation to male infertility. Int $j$ Androl. 1993;16(1): 1-13.

36. Rosemonda A, Lanottea P, Watta S. Existe-t-il un bénéfice au dépistage systématique de Chlamydia trachomatis, Mycoplasma hominis et Ureaplasma urealyticum dans les prélèvements génito-urinaires réalisés au cours d'un bilan d'infertilité ? Pathologie Biologie. 2006;54(3):125129.

37. Emokpae MA, Uadia PO, Sadiq NM. Contribution of Bacterial Infection to Male Infertility in Nigerians. J health and allied science. 2009;8:1.

38. Ali Hussein Al Marzoq, Mohammad Aboud M, Mohammad Sabri A Study of Bacterial infection associated with male infertility in Hillah city Iraq. Journal of Biology, Agriculture and Healthcar. 2012;2:9. 